\title{
Renaissance Italian Short Stories and the Imprese
}

\section{Mauda Bregoli-Russo}

The first part of tale no. 41 of Masuccio Salernitano's Novellino recounts the story of a married lady and a French knight who fall in love. The knight, named Filippo, is in the retinue of Renato Duca d'Angio, and when the Duke must suddenly return to France, the relationship between Filippo and his lady undergoes a crisis. Filippo promises that he will remain faithful and that he will return; however, he quickly forgets his promises when he becomes involved in another amorous affair in France. The lady feels spurned and abandoned but, being wise and cautious, she does not complain. Instead, she sends the knight a ring crowned with a fake diamond and inscribed with the words "Lama Zabatani" (Hebrew or Aramaic for "Why hast thou forsaken me?").

Filippo ponders the meaning of the words but cannot decipher them, nor are the other knights able to explain the strange ring and its inscription. Only the Duke, who is equal to the lady in intellect and wisdom, is able to decode the "cipher," which amounts to a veritable device, the meaning of which is "Tell me, false lover, why did you abandon me?".

The ring and its inscription do indeed constitute a device and the structure of the tale, as described above, is that of an Impresa, ${ }^{1}$ a very original one, and one worthy of attention. Not only does it appear in a tale, which glorifies the intellect of the woman who invented it, but it also couples a tridimensional object and a verbal inscription or motto, whereas other Imprese simply consist of a bidimensional figure and a motto. Moreover, the individuals involved in this Impresa are clearly outlined in the tale and distinct in their roles: the inventor of the device (an intelligent woman), the addressee (the knight), and the interpreter (the Duke).

We find that a motif similar to the one which occurs in Masuccio's novella under examination appears also in the Novelas amorosas y ejemplares (1637), by María De Zayas y Sotomayor, in the tale entitled "La Burlada Aminta y Venganza del Honor." However, an even closer and more complete parallel to this particular motif is found in Chapter 24, Book 2, of Pantagruel, written by François Rabelais in 1532. In Pantagruel, Chapters 23-4 relate the call for Pantagruel to return to his homeland to defend the Amaurotes against the invading Dipsodes, for his father has been transported to Fairyland. The same chapters also tell of Panurge's solution of the riddle of the ring which a forlorn Parisian lady had sent to Pantagruel, her unfaithful lover: 
But I can see nothing, nor do I believe that there is anything else in it than the ring. Let us, therefore, look upon it. Which when they had done, they found this in Hebrew written within, Lama sabachthani; whereupon they called Epistemon, and asked him what that meant? To which he answered, that they were Hebrew words, signifying, Wherefore hast thou forsaken me? Upon that Panurge suddenly replied. I know the mistery. Do you see this diamond? It is a false one. This, then, is the exposition of that which the lady means, Diamant faux, that is, false lover, why hast thou forsaken me? Which interpretation Pantagruel presently understood, and withal remembering, that at his departure he had not bid the lady farewell, he was very sorry, and would fain have returned to Paris, to make his peace with her. But Epistemon put him in mind of Aeneas's departure from Dido, and the saying of Heraclitus of Tarentum, That, the ship being at anchor, when need requireth, we must cut the cable rather than lose time about untying of it, - and that he should lay aside all other thoughts, to succour the city of his nativity, which was then in danger. (24.369-70)

The parallel between Chapter 24 of Rabelais's Pantagruel and tale 41 by Masuccio Salernitano is therefore based upon 1) the same motif of an inscription in Hebrew (Aramaic); and 2) the same manner of deciphering the whole, carried out in Rabelais by Panurge, and in Masuccio Salernitano by the Duke.

In addition, scattered throughout this long segment of Pantagruel, are references and allusions relating to Italy and to the Italian manner of concealing secret letters and mysterious sentences within other forms of writing. In Chapter 24, for instance, mention is made of a Messer Francesco di Nanto, a Tuscan, who wrote on how to read letters which are not apparent or visible:

Then he said to Pantagruel, Master, by the virtue of God, I cannot tell what to do or say in it. For, to know whether there be anything written upon this or no, I have made use of a good part of that which Master Francisco di Nanto, the Tuscan, sets down, who had written the manner of reading letters that do not appear. (24.369)

In short, the whole of Chapter 24 of Pantagruel, interspersed as it is with the proverbs and sayings of Erasmus, illustrates Rabelais's particular inclination for mottos, proverbs, and sayings. Chapters 18-20 of Pantagruel are also noticeably concerned with signs and symbols; Panurge, in fact, challenges the sage Thaumartes to a debate on signs.

But how can the historical transmission of the topos of the ring with the fake diamond be explained? Naturally, the connection and therefore the possibility of literary transmission between Masuccio Salernitano's tale and the episode in Rabelais's Pantagruel appears to be more direct and cogent than that between Masuccio and María De Zayas y Sotomayor. A modern critic of Rabelais, Screech, has mentioned Masuccio Salernitano as the source for Chapter 24 of Pantagruel, even though in his book he erroneously transcribes Masuccio as Masaccio:

Rabelais would doubtless have been surprised that men of good will, not mere Sorbonagres, could have seen in this good tale, retold from the Italian Masaccio, proof of hidden atheism! (97) 
It is known that both authors, François Rabelais and María De Zayas y Sotomayor, spent some time in Italy. But while Rabelais's Italian stay is proven by historical documents, the presence in Italy of María De Zayas y Sotomayor is open to some doubt, although she had occasion to read or listen to short stories by such Italian authors as Masuccio Salernitano, Matteo Bandello, Giovanni Sabadino Degli Arienti, and others.

While it is certainly possible that the Spanish writer read Masuccio Salernitano's Novellino, another possible source for the topos in her writings may be Rabelais. However, a third possibility exists for the transmission of the motif of the fake ring and the Hebrew inscription: that is, through books on Imprese and emblems.

In the course of the research carried out for the present study, an enlightening reference to this topos was discovered in the dialogue Dell'Imprese by Scipione Bargagli (1594), a copy of which is located at Chicago's Newberry Library. Bargagli's dialogue is, in reality, a learned conversation between Attonito Intronato, Mister Ippolito Augustini, and Bellisario Bolgarini. Attonito, who as an Intronato academician shows prompt and sharp wit, was asked to distinguish between an Impresa and a cipher; in other words, he was asked to be a good cipher breaker:

Am I a good decipherer? . . . Atto. (Attonito) 'If he cared at all to understand anything about this light subject it could be said, among other things, that some of these ciphers require that the voice be separate from the figure of the Impresa and that through words the quality of it may be magnified, and that through the combination of the two the whole (hidden) concept be clear. Similar is the one born of a fake diamond surrounded by the words 'Why did you forsake me?' because in splitting the word diamante his wicked quality is uncovered: Di' amante falso, perché mi hai abbandonata? (Bargagli 93)

This quotation illustrates the importance which vocal inflection can play in revealing the true meaning of an Impresa. It is clear, therefore, that neither the oral element nor the oral tradition can be neglected nor minimized in studies on Imprese.

Furthermore, what is known about the theory and history of Imprese shows that the use of Hebrew (Aramaic) in mottos is far from unusual. Luca Contile, for instance, a late sixteenth-century theoretician of Imprese, continues the work of Gerolamo Ruscelli and Scipione Bargagli in his Ragionamento ... sopra la proprietà delle Imprese (1574), in which he draws a distinction between Imprese and other similar genres, such as insignia, armour, uniforms, liveries, emblems, ornaments, backs of medals, ciphers, and hieroglyphics (c. 27 a). In speaking of the features of the motto, Contile states his preference for the Hebrew language (c. 32 a). Within this perspective, the Impresa which occurs in tale no. 41 by Masuccio Salernitano and in Chapter 24 of Rabelais's Pantagruel, because it contains a diamond as a figure and a motto inscribed in Hebrew, falls within the series of perfect Imprese. In 
addition, the importance of the vocal element in this Impresa of the fake diamond endows it with a peculiar original character.

As in ciphers, a genre cognate with Imprese, it is the voice, or oral element, which often reveals the full significance of an Impresa. One has only to recall Impresa no. 27 by Isabella d'Este Gonzaga, which contains the motto Tutte le sette dei nemici vinte [All the sects of the enemies defeated]. Impresa no. 66 by Arsiccio Intronato also comes to mind, the meaning of which is Se santa sei [If you are saint]. Another example is found in the work by Pietro Martire Scardova of Reggio, the title of which, Impresa 8 troppo, signifies "Amo Ottavia troppo." In these Imprese, as in the Impresa of the fake diamond ring, the essence of the meaning is best conveyed orally: the Impresa could not exist without the human voice, which holds the key to the quid.

In light of this data, the work of Masuccio Salernitano and François Rabelais may be viewed from a different perspective and in a new light. Chapter 24 of Pantagruel, for instance, has always received negative criticism both in past centuries as well as by modern critics, like Screech. The latter states, for example:

Not all the chapters present us with this kind of jig-puzzle of meaning to put together. Time has left many as clear now as they were then, though changes of taste have led some to see blasphemy in such an episode as the ring with its false diamond (diamant faux $)$ and its inscription LAMAH HAZABTHANI. (96-7)

In a similarly negative vein, in Jugement et observations sur la vie et les Oeuvres ... de F. Rabelais (1699), François Bernier wrote:

... que la profanation d'un mot Hebreu, si venerable a cause de celui qui l'a prononcé en mourant . . . me paroit un des endroits le plus detestables du Roman . . . (277-8)

[The profanation of a Hebrew word, so sacred because of the person who pronounced it on his death bed ... appears to me to make [Chapter 24] one of the most despicable parts in the whole novel.]

However, if we look at the Imprese as an interdisciplinary genre (rather than a separate, though parallel one) which, through the orality factor, can exert influence upon and enter into other genres: short story, drama, and lyric poetry, we are then able to modify the judgments made by literary critics on various authors of the Renaissance. In the case of Chapter 24 of Rabelais's Pantagruel, for example, we no longer need to feel horrified at the use of sacred Hebrew words in the motto and the alliance of these words with the topos of the fake diamond, when we view the whole construct within the rules relating to the theory of the Imprese. Nor do we need to seek further explanations for the transmission of the topos from Masuccio Salernitano's Italy to François Rabelais's France to María De Zayas y Sotomayor's Spain, 
because what needs to be taken into consideration in the question of historical transmission is the orality factor. The same orality which allowed the transmission of the motif of the fake diamond in France and Spain is the constitutive element of the homonymous Impresa, according to the evidence provided by Scipione Bargagli in his Imprese in 1594.

University of Illinois

\section{NOTES}

1 An Impresa is a device in which a dynamic relationship exists between figure and words (motto).

\section{WORKS CITED}

Bargagli, Scipione. Dell'Imprese. Venezia: Appresso Francesco de' Franceschi Senese, 1594.

Bernier, François. Jugement et observations sur la vie et les Oeuvres . . . de F. Rabelais. Paris: L. D'Houry, 1699.

Contile, Luca. Ragionamento di Luca Contile sopra la proprietà delle Imprese con le particolari degli Academici Affidati et con le Interpretazioni et Croniche. Pavia: Presso G. Bartoli, 1574.

Masuccio Salernitano. Il Novellino. Ed. Salvatore Nigro. Bari: Laterza, 1975 (rpt.).

Rabelais, François. The Complete Works of Doctor François Rabelais . . the Whole Faithfully Rendered Into English by Sir Thomas Urquhart and Peter Motteux, with annotations by Duchat, Ozell and others. 2 vols. London: John Lane The Bodley Head LTD., 1933.

Screech, M. A. Rabelais. Ithaca, New York: Cornell UP, 1979.

Sotomayor, María De Zayas. "La Burlada Aminta y Venganza Del Honor." Novelas Amorosas, y ejemplares. Zaragoça: Hospital Real De N. Señora De Gracia, 1637. 